\title{
Analysis of Poultry Feed Efficiency: Local Efforts to Reduce Reliance on Imported Fish Meal in Indonesia
}

\author{
Hilda Monoarfa, Chalil, Edhi Taqwa \\ Faculty of Economy \\ Tadulako University \\ Palu, Indonesia \\ hildaborman@untad.ac.id
}

\author{
Sri Sarjuni \\ Faculty of Ranch \\ Tadulako University \\ Palu, Indonesia \\ srisarjuni99@yahoo.com
}

\begin{abstract}
The times demanding people to consume nutritious foods. This triggers the more you consume chicken meat, because it was thought that the meat or animal protein had a high nutritional. Chicken as one of the cattle into meat demand by the public, this is because the meat tastes better and cheaper than the price of beef. This is what makes the demand for chicken meat increased. Increasing demand for chicken meat created a need to increase production, especially related to the efficiency of the factors of production. This study aims at the implementation of a model and strategy to increase value-added and income-based Fishermen Catch Fish Meal to reach potential Forage Poultry market in an effort to reduce dependence on imports of Fish meal here at home. It has produced in the form of animal feed products made from regional raw poultry. Implementation will be directed at the poultry farm of chicken / chicken intense systems with a comparative study of costs and growth in the use of localized feed and commercial feed. The methods used are: (1) Demonstration group of poultry broilers / village intensive system to test the effectiveness and efficiency of feed utilization of locally based and (2) Analysis of Costs, Revenues and R / C. The results showed that the use of locally-based animal feed $40 \%$ more efficient when applied on poultry farming, be it on the farm chicken or chicken pieces.
\end{abstract}

Keywords: Native Chicken, efficiency, added value, local feed.

\section{INTRODUCTION}

Sulawesi is a region which has a cluster development of fisheries and marine. Judging from the fish production in Indonesia based on distribution area, Sulawesi Economic Corridor is a region which has the largest marine fisheries. Production appears logical. This shows that the fisheries' sector is one of the main economic activities in Sulawesi Economic Corridor.

Fisheries contribute about 22 percent of total GDP, of which about 20 percent of the activity of the fishery is fishing and the rest is aquaculture. The potential development of the fishery continues to grow significantly because most of the fishery in Sulawesi is to meet the needs of exports as global demand continues to rise [1].

In order to achieve the production target sector of fisheries and marine Central Sulawesi has a direction of development, which is divided into three (3) zones are: ZONE I (Kab. Buol, Toli-Toli, Donggala, Palu), ZONA II (kab. Parimo, Poso, Tojo
Una-una); and ZONE III (Kab. Banggai, Bangkep, and Morowali) .

Observing the distribution of the above-mentioned zones, each zone can take advantage of marketing opportunities are a very high fish meals, including Tojo Una-Una both local and national. As it has been explained previously that about 75 percent of national fish floor needs are met through imports. Indonesia's dependence on imported fish is a fact which is ironic, considering Indonesia's marine resources is very abundant, where fish meal is still a major component of a protein source in feed formulations.

The results of the study [2] the potential for increased value-added fish meal-based fishermen's income is high enough seen from the results of research in the production center in Tojo Una-Una, shows production reached an average low economic value fish $25-30 \%$ of total production with a very low selling price Rp.2000 per $\mathrm{kg}$, and when it is processed into fish meal, sales value increased by $\pm 200 \%$ (the price of the fish meals Rp. 6,500 / kg). While the potential of poultry feed market in an effort to reduce dependence Indonesia imports of the fish meals, a potential which needs feed for broilers is high enough that $1,373,716.84 \mathrm{~kg} /$ cycle (22-30 days) or an average of Central Sulawesi $125,065.17 \mathrm{~kg}$ / cycle and for laying hens in Central Sulawesi as many $57915.94 \mathrm{kgs} \mathrm{/} \mathrm{months.} \mathrm{If} \mathrm{the} \mathrm{feed} \mathrm{ratio} \mathrm{of} 30 \%$ is a manufacturer of the raw material's fish meals, then it is likely absorption of the fish meals to be produced by SMEs Fishermen can be absorbed in Central Sulawesi, and will significantly reduce the burden of government that annually imports nearly $70 \%$ fish meal from other countries. Short-term goal of this research is the implementation of a model and strategy to increase value-added and income Fishermen Catch Fish Meal based to reach potential Forage Poultry market in an effort to reduce dependence on imports of Fish meal here at home. While the long-term goal to be achieved in this research is the creation of SME business clusters fish meal from the fisherme as a supplier of fish meal in animal feed processing business.

Participant's action research came from a group of fishermen and poultry broilers / village intensive systems and are all located in the district of the city Ampana. 


\section{LITERATURE REVIEW}

\section{A. Strategy Increased Added Value}

In the future, Argo-industry a locomotive national economic growth. There are at least five reasons The main sense of optimism, namely: (1) capable of processing industry changing comparative advantage into a competitive advantage, which ultimately will strengthen the competitiveness of the product; (2) product value-added Argo-industry and a large market share that may affect growth national economy; (3) argo-industries have relevance that great either upstream or downstream, to attract progress in other sectors; (4) has local raw material base (excellence comparative) to guarantee its sustainability; and (5) a chance to change the structure of the national economy from agriculture to industry. (Supriyanti and Herlina, 2012).

Furthermore, explained there are four key elements in the development of rural agro industri namely (1) Agglomeration companies (cluster); (2) Increasing the value added (value added) and the value chain (value chain); (3); (3) supplier network through partnerships (partnerships) and customers; and (4) the economic infrastructure network of physical and non-physical. The key element that was instrumental in the development of an agro-industrial-based marine fishery, as well as the results of the study Chalil and Bappeda Kab. Donggala (2007), explains that the four dimensions (cluster, value added, value chain, customer partnership) is apparently the simultaneous effect of $89.5 \%$ to the development of agro-industry enterprises based marine fisheries. However, partially dominant influence agroind $\mathrm{u}$ stri-based development of marine fisheries is a network of suppliers through partnerships, and increase added value.

The main problem is a local producer of fish meal supply fluctuates, and the quality is low (easy to rancidity, high-fat and low protein content (30-40\%) (kabarbisnis.com). When the fish powder manufacturing technology is adopted, then the fish meal produced better quality as animal feed, with a lower water content $(8-10 \%)$ and nonfat made free from rancidity (Dirjenak, 2010). consequents fish meal less fat in dry matter basis is the same, it will increase the content protein. One of the characteristics of fish meal quality first is due to the high content of protein $(60 \%)$ generated through the release of fat content. Other factors that influence quality fish meal is a raw material. fishmeal is made from offal fish (a component of fish that are not consumed, such as the head, skin and entrails) has a lower protein content than a fish meal made from whole fish. Below, show the added value of the fish into fish meal.

Conditions Fishermen Fish in Tojo Una-Una, in terms of revenue is relatively small. Many factors affect the size of Fishermen Catch income, among other substantial operational costs, meaning that fishermen will need a working capital one fishing Rp. 5-7 million / week for medium-scale motor boats with fishing gear. As it is expressed by Hilda (2009) that the net income after subtract the total costs, the Fishermen Capture can still enjoy the benefits of approximately $25 \%$.

\section{B. Market Potential}

Indonesia famous maritime country rich in fish, it still imports of the fish meals. In 2012, import of the fish meals is less than 76, 35 thousand tons worth US \$ 94.08 million. While the total estimated consumption of animal feed of 13.5 million tonnes comprising 12.3 million tonnes of animal feed (corn, soybean) and 1.2 million tonnes of fish feed / year. Imports of fish meal coming from various countries such as Malaysia and Vietnam, Thailand, RRChina, Taiwan, and Japan. (Trobos Aqua, 2012). In addition, the Chairman of the Indonesian Aquaculture Feed Manufacturers Association Indrajaya Denny (2013) revealed the fish meal production capacity in Indonesia is only about 45,000 tons, or $30 \%$ of total demand each year. Indonesia still relies heavily on fish meal imported from Thailand and Vietnam.

Observing the high imports of the fish meals, indicating that the market opportunity is still wide open. Therefore, with the ability to produce fish by Fishermen Catch quite high, especially in the less valuable fish species will be improved in Tojo Una-Una. As the result of research Hilda da Department of Marine (2011) revealed that of the socio-economic aspects and the outpouring of the time or frequency at sea it would impact the amount of production or fishermen in Tojo UnaUna. Total production, partly the result, mainly snapper used as salted fish, so that value-added revenue increases. If the raw snapper in the selling price is only $25.000 \mathrm{per} / \mathrm{kg}$, whereas when dried into a salted fish selling price Rp.45.000- 50,000 per $\mathrm{kg}$. This shows an increase in value-added profit margin's high enough average of $100 \%$. However, the snapper type of fish at sea or in one production only reached $15 \%$.

\section{METHODS}

Interactive discussions with the model Focus Group disscussion $(F G D)$ to discuss specific issues in detail in accordance with the purpose of research. Participants action research came from a group of fishermen and poultry broilers / village intensive systems and are all located in the district of the city Ampana. The analytical method used is: (1) Analysis of quantitative and qualitative; (2) Action Research (Demonstration on broiler farms / chicken intensive system based animal feed and commercial feed to measure efficiency and effectiveness.

\section{RESULT}

\section{A. Geography, climate, and population}

Tojo Una-Una with an area of $5721.51 \mathrm{~km} 2$ is one of regencies in Central Sulawesi province that has natural support with potentially high. Diversity and completeness of the topology of the area from the sea to the highlands region would provide a tremendous opportunity to be managed and utilized properly.

Geographically Tojo Una Una- lie at coordinates $0{ }^{\circ} 06 ' 56$ " to $2^{\circ} 01^{\prime} 41$ " South latitude and $121^{\circ} 05^{\prime} 25^{\prime \prime}$ up to $123{ }^{\circ}$ $06 ' 17$ " East Longitude. Judging from the boundary, north Tojo Una-Una bordering the Gulf of Tomini and Gorontalo and in the south by the Morowali district. In the West and East respectively Poso regency and Banggai. 
The average air temperature in Tojo Una-Una in 2012 ranging from $17{ }^{\circ} \mathrm{C}$ to $33{ }^{\circ} \mathrm{C}$ with a wind speed of 3-6 knots. The areas immediately adjacent to the coast generally have an average air temperature is relatively high. While the average air humidity varies between 74 percent to 82 percent. Throughout the rainy season in 2012, the number of rainy days in the District Ampana City as a regional center of the district capital, there were 104 days with precipitation levels of 1202.6 $\mathrm{mm}$.

The population of Tojo Una-Una is based on the estimated number in 2012 reached 141906 people, made up of 72828 inhabitants of the male and female population of 69078 inhabitants, so it has a sex ratio of 105 . This ratio is equal to the ratio in the age group 0-14 years, while the ratio in the age group 15-64 years is likely to increase, which amounted to 107. in contrast, the ratio in the age group> 65 relatively decreases in the amount of 94 . If you look at the composition of the population by age, it appears that residents of Tojo UnaUna relatively young structured or adult. Another thing that can be seen from the population pyramid is a change in direction of development of the population that is characterized by the smaller number of population aged $0-4$ years compared to 5-9 years old. This condition means that the government managed to maintain a low growth rate.

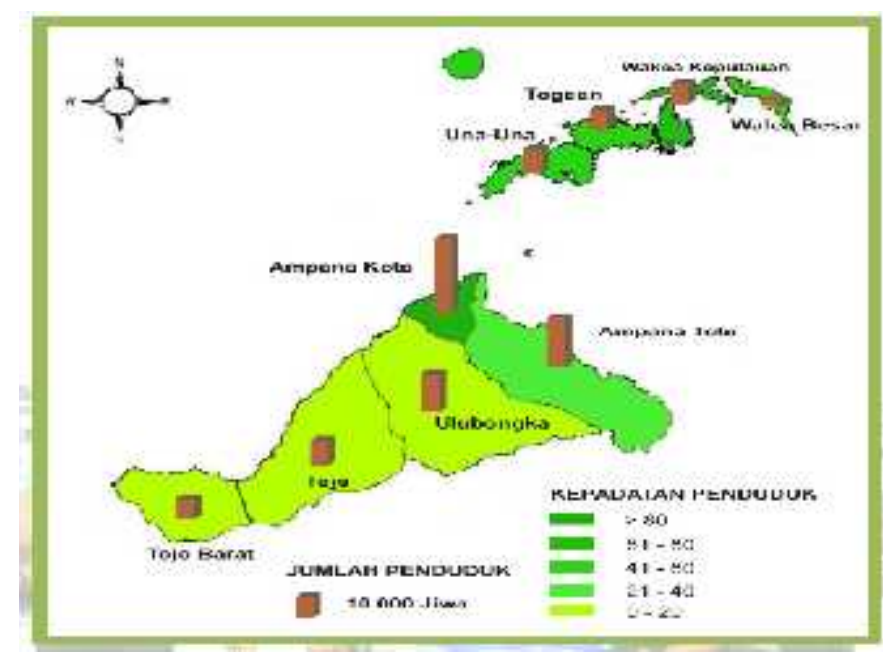

Fig. 1. Map Tojo Una-Una. Source: BPS Tojo Una-Una in Figures, 2013.

\section{Production of fisheries}

Tojo Una-Una area with natural potential is quite large, agriculture, plantation, forestry, hunting and fishing be chosen by the public in Tojo Una-Una as a livelihood. In 2012, the percentage of the workforce in this sector reached 56.29 percent. Followed by social services sector, social and personal with labor absorption percentage of 12.46 percent. While the percentage of the workforce that is absorbed in the industrial sector amounted to only 6.80 percent.

Tojo Una-una has unique characteristics, which are geographically divided into two, namely land and sea. For marine areas 4 (four districts) and a land area there are 5 districts. Marine fish production in the region is the highest kepulawan District of Una-una. While in the region's largest onshore production is Ampana District of the City and District of Tojo. Una-Una, and District Tojo. However, the production of almost $25 \%$ of fish caught is low economic value. For example, anchovy, flat white (bete-bete local language), and a single small fish.

\section{B. Potential Commodities Corn As Livestock Feed Source}

The agricultural sector is a sector that provides the largest contribution in the economy of Tojo Una-Una. One commodity crops which is the mainstay of corn, where production reached 52599 tonnes in 2012. In addition to corn production declines over the last three years, other food crops have increased production. Commodity whose production increased significantly was rice and soybeans. Three of these commodities are feedstuffs very good mix in addition to fishmeal.

\section{Poultry Feed Market Potential as Efforts to reduce reliance on imports Fish Meal Indonesia}

Rustam research, et al (2013) suggests that the need for animal feed Poultry in Central Sulawesi High Enough. It is based on the conclusions of which describe His research on several things, among others:

a) Total needs cock broilers in Central Sulawesi as much $3,804,225.68 \mathrm{~kg}$ or an average Sulteng amounted to $345,838.70 \mathrm{~kg} /$ month which is equivalent to $197,622.11$ tail / mo. Total needs eggs in Central Sulawesi as much $1,514,689.83 \mathrm{~kg}$ or an average Sulteng $137,699.00 \mathrm{~kg} /$ month or equivalent to $2,478,582.05$ grains / mo.

b) A total lack of inventory for broilers in Central Sulawesi, as much as - 3,367,285.68 kg / month or an average of Central Sulawesi $-306,116.88 \mathrm{~kg} /$ month which is equivalent to - tail $174,923.93$ / month. The total shortage of eggs in Central Sulawesi as much $-1,492,248.20 \mathrm{~kg}$ or an average of Central Sulawesi $-135,658.93 \mathrm{~kg} /$ month which is equivalent to $-2,441,860.69$ grains / month.

c) Total feed requirements (mills, corn, and rice bran) for broilers in Central Sulawesi as much 1,373,716.84 kg / cycle (22-30 days) or an average of Central Sulawesi $125,065.17 \mathrm{~kg} /$ cycle. Total feed requirements (mills, corn, and rice bran) for laying hens in Central Sulawesi as much as $57915.94 \mathrm{~kg} /$ month or an average of Central Sulawesi is equivalent to $6435.10 \mathrm{~kg} / \mathrm{month}$.

d) Total needs of local raw material feed corn for broilers in Central Sulawesi as much as $695,563.32 \mathrm{~kg}$ or an average of Central Sulawesi as much as $63233.03 \mathrm{~kg} /$ month. As for the total requirement of bran feed $271,623.47 \mathrm{~kg} /$ month or an average of Central Sulawesi $24693.04 \mathrm{~kg} /$ month. Total maize requirement for laying hens effort as much as $35759.18 \mathrm{~kg}$ or an average of Central Sulawesi $3250.83 \mathrm{~kg} /$ month. As for the bran feed, total needs as much as $13413.20 \mathrm{~kg} /$ month or an average of Central Sulawesi as much as $1219.38 \mathrm{~kg} /$ month.

e) Feed costs based on the survey results, level broiler breeder requires a fee of Rp. 16342.39 oak / cycle equivalent to $2.85 \mathrm{~kg} /$ cycle while laying hens require a 
fee of Rp. 12457 oak / month or equivalent to $3.49 \mathrm{~kg} /$ oak / mo.

Looking at these figures above, especially at points (5) and is associated with a point (3) in which the needs of feed for broilers is high enough that $1,373,716.84 \mathrm{~kg} /$ cycle $(22-30$ days) or an average of Central Sulawesi 125,065.17 kg / cycle, and for laying hens in Central Sulawesi as much as 57915.94 $\mathrm{kg} /$ month or an average of Central Sulawesi is equivalent to $6435.10 \mathrm{~kg} /$ month. If the feed ratio of $50 \%$ is a manufacturer of raw materials fish meal then it confirmed the absorption of fish meal to be produced by SMEs Fishermen can be absorbed in Central Sulawesi, and will significantly reduce the burden of government that annually imports nearly $70 \%$ of fishmeal from other countries. And we have the ability to produce, especially in the production centers fishermen catch. If the industry is built, then the income of fishermen will increase and welfare can be met.

\section{Livestock Business Analysis Native Chicken \\ - Business Analysis}

Results of research and business management assistance Balitbangda, Hapsah, et al (2014) in collaboration with the Youth Forum Kaili Post-Conflict in Palu, the management Sector Enterprises Poultry village by utilizing local feed. Results mentoring shows that farm chicken cage system intensef and make their own food utilizing local feed deserve to be developed, with consideration of local potential such as the availability of potential yellow corn, bran, and tofu or soy and flour anchovies previously lacked high economic value at the time of abundant stocks.

Furthermore, on a modern poultry farm, feed costs can reach $70 \%$ of the production cost. Poultry intensive effort is characterized by high productivity of broiler chicken (broiler) to achieve weight loss of $1.5 \mathrm{~kg}$ in 32 days, laying hens produce more than 300 items in 1 year, and domestic poultry (chicken) can reach a live weight of $850 \mathrm{~g}$ in 2 months.

\section{- Business Management}

Field assistance in the form of mentoring manner routinely record the amount of feeding, chicken and schedule status in case. This recording determining the continuity in the calculation of costs that could affect the final value of the business profits. UAT daily recording dib 1 RII while observing the state of the field as the condition of the number of chickens that live today the amount of feed given on the day of the technical things like vaccines / vitamin for certain circumstances.

\section{a) Maintenance phase relationship with Feed Intake}

Based on the growth phase from week 1 to week 5 , can be explained as follows.

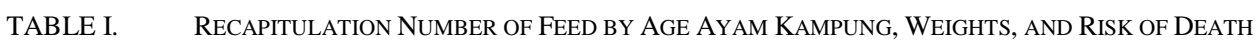

\begin{tabular}{|l|l|l|l|l|}
\hline \multicolumn{1}{|c|}{ Week } & \multicolumn{1}{|c|}{$\begin{array}{c}\text { The amount of } \\
\text { feed (kg) }\end{array}$} & $\begin{array}{c}\text { Amount } \\
\text { Chicken (tail) }\end{array}$ & \multicolumn{1}{|c|}{$\begin{array}{c}\text { Dead } \\
\text { (tail) }\end{array}$} & $\begin{array}{c}\text { Mean Weight } \\
\text { (GRM) }\end{array}$ \\
\hline $1-2$ & 370 & 2000 & 27 & 12.43 \\
\hline $3-4$ & 820 & 1973 & 13 & 308.97 \\
\hline 5 & 1,384 & 1970 & 3 & $500-800$ \\
\hline amount & $\mathbf{2 , 5 7 4}$ & & $\begin{array}{l}\mathbf{4 3} \\
\mathbf{( 2 . 1 5 \% )}\end{array}$ & \\
\hline
\end{tabular}

\section{b) Analysis of Production Costs}

In the livestock business management is necessary a cost analysis, in order to make known whether these efforts mengungungkan or not, so that the cost anlisis business continuity can be determined. The table below provides information for decision makers whether the business is profitable or a loss. Assumptions used to calculate the cost of the data of science and technology as follows: List Price Feed Ingredients Used from Local Market (Level Retailers):

TABLE II. THIS TYPE OF MATERIAL AND PRICES

\begin{tabular}{|l|l|l|}
\hline No. & \multicolumn{1}{|c|}{ Raw material } & \multicolumn{1}{|c|}{ Price } \\
\hline 1 & Corn & $\operatorname{Rp~} 3,500$ \\
\hline 2 & Bran & $\operatorname{Rp~} 2,500$ \\
\hline 3 & Fish & $\operatorname{Rp~} 20,000$ \\
\hline 4 & Soy & $\operatorname{Rp~} 13,000$ \\
\hline 5 & Tofu & $\operatorname{Rp~} 1,500$ \\
\hline 6 & Premix & $\operatorname{Rp~} 24,000$ \\
\hline
\end{tabular}


Based on Table II. Above, maka sump compositions can be prepared early standard Local feed production as follows:

TABLE III. Local Raw Materials, FeEd COMPOSITION ANd BASIC PRice FeEd

\begin{tabular}{|c|c|c|c|c|c|c|}
\hline \multirow[t]{2}{*}{ No. } & \multirow{2}{*}{$\begin{array}{l}\text { Feed Raw } \\
\text { Materials }\end{array}$} & \multicolumn{2}{|c|}{ Feed composition, \% } & \multicolumn{3}{|c|}{ Feed Composition (USD) } \\
\hline & & Starter & Grower & Starter & Grower & Average \\
\hline 1. & Corn & 49 & 49 & 3,472 & 3,214 & 3,343 \\
\hline 2. & Bran & 11 & 14 & 779 & 918 & 849 \\
\hline 3. & Fish & 15 & 12 & 1,063 & 787 & 925 \\
\hline 4. & Soy & 13 & 13 & 921 & 853 & 887 \\
\hline 5. & Tofu & 11 & 11 & 779 & 722 & 750 \\
\hline 6. & Premix & 1 & 1 & 71 & 66 & 68 \\
\hline & amount & 100 & 100 & & & \\
\hline & $\begin{array}{l}\text { Basic Price, Rp / } \\
\mathrm{kg}\end{array}$ & 7085 & 6,560 & 7085 & 6,560 & 6823 \\
\hline & \multicolumn{3}{|c|}{$\begin{array}{l}\text { Commercial Feed price: IDR } 9,000 / \mathrm{kg} \text {, the level of } \\
\text { efficiency of local feed } \mathbf{\pm 3 1} \%\end{array}$} & & & \\
\hline
\end{tabular}

c. Balitbangda, Hapsah, ddk (2014)

Based on the table above, it appears that by making and giving $\mathrm{k}$ an intake of locally-based animal feed more efficiently than the manufacturer that feed efficiency level of approximately
$31 \%$. Additionally, organic chicken has the advantage that is healthy and safe, because it is free of chemicals. The composition of the feed research in the field of science and technology and convert at a price it can be arranged cost analysis as shown in the following table:

TABle IV. Analisa Biaya Produksi, Proyeksi Pendapatan dan KeUntungan

\begin{tabular}{|c|c|c|c|c|}
\hline No & Ura & & & Jumlah (Rp) \\
\hline 1 & Penerimaan hasil (1000 ekor) @ Rp.50.000/el & & \multirow{7}{*}{925.000} & $50.000 .000,00$ \\
\hline \multirow[t]{12}{*}{2} & Biaya : & & & \\
\hline & A. Biaya Tetap (BT) & & & \\
\hline & - Sewa kandang & 700.000 & & \\
\hline & - Listrik & 100.000 & & \\
\hline & - Adm/ Iuran anggota & 25.000 & & \\
\hline & - Penyusutan Alat & 100.000 & & \\
\hline & B. Biaya Variabel (BV) $(\mathrm{Rp} / \mathrm{Ha})$ : & & 21.901 .867 & \\
\hline & - Bibit & 9.500 .000 & & \\
\hline & - Pakan & 10.301 .867 & & \\
\hline & - Biaya Pengolahan Pakan (BBM) & 100.000 & 313 & \\
\hline & - Obat/Vit & 1.000 .000 & & \\
\hline & - Tenaga Kerja & 1.000 .000 & & \\
\hline 3 & Total Biaya $(\mathrm{BT}+\mathrm{B}$ V) & & & 22.826 .867 \\
\hline 4 & Pendapatan Usaha Ternak Ayam & & & 27.173 .133 \\
\hline 5 & $\mathrm{R} / \mathrm{C}$ & & & 2,19 \\
\hline
\end{tabular}




\section{Livestock Business Assistance Pilot Implementation of Native Chicken Feed System Based Intensive Local In Tojo Una-Una}

"In the applied research will be planned implementation in August to September 2015, the support of local government funds have been allocated in the Budget Supplement (ABT) in 2015 amounted to Rp. 197. 000.000.- (One Hundred Ninetyseven Million). The allocation of these funds are used for the construction of the enclosure. feed processing equipment purchases, maintenance, and monitoring and evaluation governments and researchers.

Based on the above and look at the potential of local feed in Tojo Una-una, the estimated cost of raw materials such as corn, soybean meal and be more efficient.

Based on the results of descriptive analysis shows that the respondents' assessment of the implementaion Frame model and strategy of adding value. Of the three districts, the average value in the category above 4 means critical. For more detail can be presented in the following table.

Decribtive analisys result that the variables that have the highest value for the District of Una-Una is improve access to capital through banks and weak is the ability to increase production. While the District of Tojo highest value is the same as the District of Una-Una, but are still weak, namely monitoring and evaluation of government programs are sustainable. Furthermore, the City Ampana the highest value is the ability to increase production and weak: the ability to develop the entrepreneurial spirit commodity-based marine fisheries. On the other hand, the respondents' assessment of the increase in the average value added in the category value above 4 , which gives a meaning that is very important in adding value to be pursued.

Based on observations showed in the district. Tojo Una-Una, to attempt broilers and laying hens large scale there is only one (1) ie Breeders Partners. These partners work with small-scale broiler breeders, with the supply of seedlings (DOC) to the feed supply and marketing.

Analysis of the cost of feed for farm needs chicken local feed-based intensive systems can save approximately $31 \%$. That is, if the feed itself can be cultivated by farmers, it will grow poultry farm in Tojo Una-Una. Because today there is only one large business scale farmers with the sale of 75,000 head per year, or an average of 300 individuals per day, by utilizing the feed manufacturer. Likewise, businesses laying hens only one, with average sales of 870 racks / week. The main obstacle farm businesses today is the availability of feed manufacturers are relatively expensive, and feed the largest component $(70 \%)$.

\section{DISCUSSION}

1. Development of fish meal with a system of marketing partnership contract with farmers in Tojo Una-Una

2. Development of a standard export quality fish meal.

\section{CONCLUSION}

Analysis of the cost of feed for farm needs chicken local feed-based intensive systems can save approximately $31 \%$. That is, if the feed itself can be cultivated by farmers, it will grow poultry farm in Tojo Una-Una. Because today there is only one large business scale farmers with the sale of 75,000 head per year, or an average of 300 individuals per day, by utilizing the feed manufacturer. Likewise, businesses laying hens only one, with average sales of 870 racks / week. The main obstacle farm businesses today is the availability of feed manufacturers are relatively expensive, and feed the largest component (70\%).

Limitations of this study lies in the addition to the geographical location that is difficult to reach by the current study. Further research is to develop aspects of the marketing of livestock feed and also to examine the feed for cows and goats.

\section{REFERENCES}

[1] Wirabrata, H. 2000. Pengembangan Klaster Industri Antara Teori dan Praktek. Jakarta: Departemen Perindustrian.

[2] Hilda, Chalil, dan Edhi, 2014. Pengembangan UKM Sektor Perikanan dan Kelautan (dalam Perspektif Potensi Pasar Pakan Ternak Unggas). Palu: Penerbit Mitra Prima.

[3] Supriyati dan Herlina Tarigan 2012. Prospek perunggasan. Pusat Analisis Sosial Ekonomi file:///C:/Users/Toshiba/Documents/TEPUNG\%20IKAN/prospek\%20te pung\%20ikan.htm

[4] Tarwiyah, Kemal, 2001. Teknologi Tepat Guna Agroindustri Kecil. Sumatera Barat: Dewan Ilmu Pengetahuan, Teknologi dan Industri Sumatera Barat

[5] Hilda dan Chalil, 2009. Analsis Biaya Produksi dan Pendapatan Nelayan Tangkap di Kabupaten Tojo Una-Una.

[6] Trobos Aqua, 2012. Jinakkan hulunya, lancarkan hilirnya. Jakarta: PT. Permata Wacana Listari

[7] Danny Inraya, 2013. Industri perikanan nasional membutuhkan produksi minimal 150.000 ton. Jakarta: Pengusaha Muslim Indonesia.

[8] Hilda dan Dinas Perikanan dan Kelautan, 2011. Analisis Sosial Ekonomi Nelayan tangkap dan Peningkatan Nilai Tambah Pendapatan dengan sistem pengolahan Ikan Kering jenis Kakap di Daerah Kepulauan Kabupaten Tojo Una-Una

[9] Sekaran, Uma, 2004. Research Methods for Business, A Akill-Building Approach. Thirt Edition, John Wiley \& Sons, Inc., America.

[10] Rosida P.Adam, Yusak Tommy, dan Hengki Wowilling (2014).. Kajian Manajemen dan Pendampingan Usaha Ternak. Palu: Balitbangda Provinsi Sul-Teng.

[11] Balitbangda, Hafsah, Moh. Iqbal dan Ilham (2014). Aplikasi Teknologi Pengolahan Pakan Lokal Ternak Unggas. Palu: Balitbangda Prov. Sulteng 